Research Paper: SW-Soil and Water

\title{
Water use and response of a dry-farmed olive orchard recently converted to irrigation
}

\author{
Francisco L. Santos ${ }^{a, *}$, Pedro C. Valverde ${ }^{a}$, Alice F. Ramos ${ }^{b}$, \\ João L. Reis ${ }^{a}$, Nádia L. Castanheira ${ }^{a}$ \\ anstituto de Ciências Agrárias Mediterrânicas, University of Évora, Évora, Portugal \\ bEscola Superior Agrária de Beja, Beja, Portugal
}

\section{A R T I C L E I N F O}

Article history:

Received 6 July 2006

Accepted 26 March 2007

Available online 20 July 2007
Experimental results obtained in Southern Portugal from a dry-farmed mature olive tree orchard recently converted to drip irrigation are described. Water use and response to two irrigation management practices by olive trees was monitored with sap flow compensation heat pulse sensors, 'Watermark' granular matrix block sensors and a capacitance probe. The 80-plus-year-old mature olive tree orchard planted on a $12 \mathrm{~m}$ by $12 \mathrm{~m}$ spacing layout was converted in 2005 from dry-farming to drip irrigation and subjected to two water treatments: trees irrigated daily to supply for crop water demand and trees irrigated beforeflowering, during pit-hardening and before crop-harvesting. Sap flow sensors were implanted in sample trees at three different positions around the trunk and measurements were taken at $30 \mathrm{~min}$ intervals during 4 months, from April to mid-August of 2005. Tree transpiration rates were estimated as average of sap flow rates. When trees were fully irrigated, the observed differences in daily sap flow rate amplitude were explained by the natural trees difference in canopy cover, plant height and conductance of water vapour sites. However, when deficit irrigation was prescribed and, when the trees stopped being irrigated, they gradually lost their ability to adequately respond to the evaporative demands of the day, showing smaller variations in amplitudes sap flow. After irrigation ceased in May 15, transpiration rate gradually decreased from its maximum of $71 \mathrm{~h}^{-1}$, when trees were fully irrigated and soil water content was near to field capacity, to values of less than $31 \mathrm{~h}^{-1}$ by July 3 as the soil water content gradually acted as the transpiration limiting factor. Transpiration rates recovered after irrigation was re-introduced on July 4 . Although low in the non-irrigation period, transpiration rates never dropped to zero and stayed between 37 and $50 \mathrm{ld}^{-1}$ from May 27 to June 9 , as trees were able to extract soil water in the absence of irrigation. Olive trees maintained transpiration to levels as high as $501 \mathrm{~d}^{-1}$ suggesting that long after irrigation is suppressed, a considerable amount of water held in the soil is made available to the trees. Differences in evapotranspiration and transpiration rates during the same period also indicated that olive trees, making use of the extensive root system developed in the $12 \mathrm{~m}$ by $12 \mathrm{~m}$ tree spacing, were able to extract soil water and maintain transpiration levels as high as $50 \mathrm{ld}^{-1}$, while soil water balance indicated tree evapotranspiration rates close to zero. This particular ability of dry-farmed olive trees to remove water held in the soil under adverse conditions of very low soil moisture and uncertainties associated with the real volume of soil effectively explored by the root system, make profile probe sensors, regardless of their accuracy, unsuitable for control of water uptake and management of dry-farmed olive orchards recently converted to irrigation. Likewise,

\footnotetext{
*Corresponding author.

E-mail addresses: fls@uevora.ptf (F.L. Santos), aramos@esab.ipbeja.pt (A.F. Ramos). 1537-5110/\$- see front matter ( 2007 IAgrE. Published by Elsevier Ltd. All rights reserved. doi:10.1016/j.biosystemseng.2007.03.027
} 
watermark sensors, able to capture the variations of high soil water, failed to provide meaningfully values below $0.28 \mathrm{~cm}^{3} \mathrm{~cm}^{-1}$. Both sensors should be used with care in managing irrigation of olive tree orchards and, rather than relying on soil moisture status, monitoring tree water-use and response with the compensation heat-pulse method seems a more appropriate approach.

c) 2007 IAgrE. Published by Elsevier Ltd. All rights reserved.

\section{Introduction}

Due to the characteristically infrequent and limited annual rainfall in the Mediterranean regions, there is a growing interest in improving the water-use of olive tree orchards as most modern olive orchards are drip irrigated and water availability for agricultural use is often scarce. Olive is a strategic crop in the Mediterranean basin, highly adaptable to drought and known to attain acceptable productions even under dry farming. Nevertheless, the irrigation of olive trees has proven to be important, leading to yield increases and better fruit quality (Fernández \& Moreno, 1999). Deficit irrigation management practices often imposed by low water availability can maximise yield returns and provide economic benefits. The optimisation of irrigation management practices requires more research done on olive tree response to water stress through regulated deficit irrigation and efficient irrigation management programmes.

Water-use for olive production has been studied mainly through soil water availability and the influence of local weather on tree soil water consumption. However, soil heterogeneity, which requires the setting up of a considerable number of sensors to achieve acceptable representation of the effective portion of water held in the soil and used by the tree, often makes the information spatially disperse and difficult to use. It is also known (Xiloyannis et al., 1999) that to cope with water stress and effectively mobilise soil water, olive trees establish high potential gradients between the leaves and roots to extract soil water up to $-2.5 \mathrm{MPa}$. Irrigation control based on such measurements is unreliable as most soil moisture sensors are often unable to correctly evaluate soil water potential at such low values.

Rather than relying on soil moisture status physiologically based indicators of plant water status are used. This 'plant needs'-based approach uses the tree as a biosensor to monitor the plant water status and its physiological responses to external factors like local atmospheric demand for water and soil water availability. One such approach that has been successfully used for olive trees is the compensation heat-pulse method (CHP) to monitor tree sap flow and transpiration (Green \& Clothier, 1988; Fernández et al., 1998, 2001; Green et al., 2003). It uses heat as a tracer for ascending sap movement in stems and trunk. The conductive woody tissue is heated and heat dissipation is assessed from temperature measurements in two locations of the plant stem. The technique requires appropriate sampling (Smith \& Allen, 1996) and careful evaluation of the control points (Jones, 2004). The purpose of this paper is to report on the suitability of heat-pulse technique to measure sap flow, evaluate transpiration and real-time olive trees water use and response in Southern Portugal. Tree evapotranspiration rates due to changes in atmospheric evaporative demand and soil water availability under full and regulated deficit irrigation (RDI) are also reported.

\section{Material and methods}

\subsection{Experiment location and irrigation management}

The research was conducted during 2005 at the Herdade dos Lameirões located near Safara (lat. $38^{\circ} 05^{\prime} \mathrm{N}$; long. $07^{\circ} 16^{\prime} \mathrm{W}$; alt. $75 \mathrm{~m}$ ), in the region of Moura, Alentejo, Portugal, on an orchard stand of 269 mature olive trees (Olea europaea L. var. Cordovil). The 80-plus-year-old mature olive orchard planted on a $12 \mathrm{~m}$ by $12 \mathrm{~m}$ spacing layout was converted in 2005 from its originally dry-farming to drip irrigation and submitted from mid-March to the end of August 2005 to two different irrigation treatments: treatment A with full-irrigation of 78 trees to provide for approximately $100 \%$ of crop evapotranspiration $E T_{c}$, and one regulated deficit irrigation (RDI) or treatment $\mathrm{C}$. In treatment $\mathrm{C}$, water is applied to 60 trees only during three critical phase periods: before-flowering, during pit-hardening and before crop harvesting, to provide for $100 \%$ of $\mathrm{ET}_{\mathrm{c}}$. Crop evapotranspiration was calculated using the FAOPenman-Monteith method and procedures prescribed by Allen et al. (1998). Each tree was water supplied by a single drip line with emitters spaced $1 \mathrm{~m}$ apart throughout the entire length of the emitter line placed at the soil surface and laid out along each tree row and serviced by twelve $3.61 \mathrm{~h}^{-1}$ emitters. Weather data and rainfall events were collected by an automatic weather station. For the year 2005, the total rainfall of $194 \mathrm{~mm}$, recorded from October 1 of the preceding year to September 30 of following year, was exceptionally low, well below the annual average of $580 \mathrm{~mm}$ for the region.

\subsection{Sap flow measurements}

To evaluate sap flow rates and transpiration, a representative tree in each water treatment was selected and implanted with heat pulse probes. Using the compensation heat-pulse technique (CHP) described in Green and Clothier (1988) and Green et al. (2003), sets of one heat source and two temperature probes (Fig. 1) were implanted in each sample tree at three different positions around the trunk. Sap flow measurements of treatment $A$ and treatment $C$ were taken at 30 min intervals during 4 months from April to mid-August of 2005 and tree transpiration rates were estimated as average sap flow rates of the three probes. Each temperature probe houses a set of copper-constantan thermocouple junctions 


\begin{tabular}{|c|c|c|c|}
\hline \multicolumn{2}{|c|}{ Nomenclature } & $t_{1}$ & interval initial time, min \\
\hline D & drainage, $\mathrm{mm}$ & $t_{7}$ & time elapsed after heat pulse release s \\
\hline EC & electric conductivity $\mathrm{dS} \mathrm{m}^{-1}$ & $X_{d}$ & distance between heater probe and downstream \\
\hline $\mathrm{ET}_{0}$ & FAO- Penman-Monteith potential evapotranspira- & & temperature probe, $\mathrm{mm}$ \\
\hline & tion, $\mathrm{mm}$ & $X_{u}$ & distance between heater probe and upstream \\
\hline $\mathrm{ET}_{\mathrm{C}}$ & crop evapotranspiration, $\mathrm{mm}$ & & temperature probe, $\mathrm{mm}$ \\
\hline$h$ & heartwood radius, $\mathrm{mm}$ & $z_{1}$ & soil initial depth of interval, $\mathrm{mm}$ \\
\hline$h$ & water pressure head, cm & $z_{2}$ & soil final depth of interval, mm \\
\hline I & irrigation water, $\mathrm{mm}$ & $\alpha, \lambda, \eta$ & Mualem-Van Genuchten fitting parameter \\
\hline K & hydraulic conductivity, $\mathrm{cm} \mathrm{d}^{-1}$ & $\Delta S$ & variation in soil water storage, $\mathrm{mm}$ \\
\hline$K(h)$ & $\begin{array}{l}\text { hydraulic conductivity (as a function of water } \\
\text { pressure head } \mathrm{h}), \mathrm{cm} \mathrm{d}^{-1}\end{array}$ & $\begin{array}{l}\Delta \mathrm{t} \\
\Delta \mathrm{z}\end{array}$ & $\begin{array}{l}\text { time interval, } \mathrm{h} \\
\text { soil depth interval, } \mathrm{cm}\end{array}$ \\
\hline$K_{\mathrm{s}}$ & saturated hydraulic conductivity, $\mathrm{m} \mathrm{d}^{-1}$ & $\theta$ & soil water content, $\mathrm{cm}^{3} \mathrm{~cm}^{-3}$ \\
\hline$R$ & measured rainfall, $\mathrm{mm}$ & $\theta_{r}$ & residual soil water content, $\mathrm{cm}^{3} \mathrm{~cm}^{-3}$ \\
\hline$r$ & sapwood depth, mm & $\theta_{\mathrm{s}}$ & saturation soil water content, $\mathrm{cm}^{3} \mathrm{~cm}^{-3}$ \\
\hline $\mathrm{R}$ & trunk radius, $\mathrm{mm}$ & $\psi$ & soil matric water potential, $\mathrm{MPa}$ \\
\hline SAR & sodium absorption ratio, meq $\mathrm{l}^{-105}$ & & \\
\hline
\end{tabular}

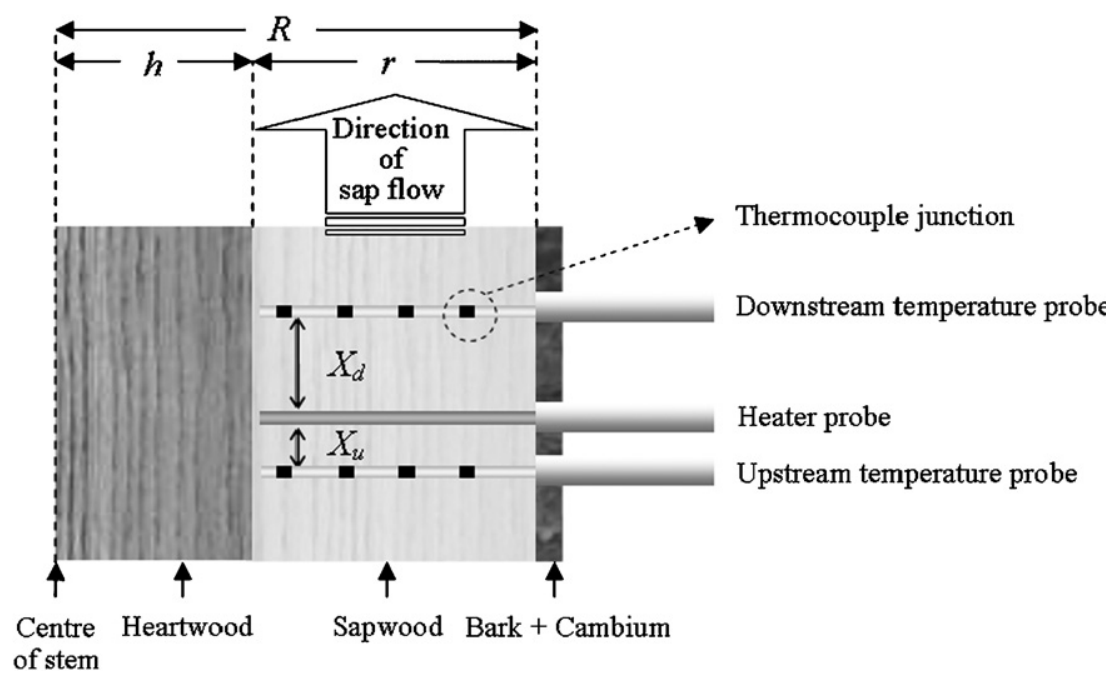

Fig. 1 - Cross-section layout of compensation heat-pulse probes for sap evaluation in a plant stem: $R$, stem radius; $h$, radius of the heartwood; $r$, sapwood depth; $X_{d}$, distance between heater probe and downstream probe; $X_{u}$, distance between heater probe and upstream temperature probe.

placed at different distances inside a $1.7 \mathrm{~mm}$ Teflon tube. The sap flow probes had four thermocouple sensors at 5, 12, 21 and $35 \mathrm{~mm}$ depth. The heater probes are made of $1.63 \mathrm{~mm}$ stainless-steel tube containing a nichrome resistance. The probes and associate equipments supplied by Green (2004) were connected to Campbell CR10X data loggers (Campbell Scientific Instruments, Logan, UT, USA) and installed by drilling holes into the sapwood. The required spacing between probes was preserved by drilling the holes with the help of a guiding jig. Fig. 1 shows the configuration of a single set of heat-pulse probes implanted into a tree stem.

In each sampled tree, the trunk radius $R$ was evaluated and the heartwood radius $h$ deduced from sapwood depth $r$, visually established from colouration changes in the core samples obtained with a $150 \mathrm{~mm}$ Suunto increment core borer. For each set of probes and at $30 \mathrm{~min}$ intervals, the data- logger turns on the heater probe for a short period (0.5-1s), releases a heat pulse in the sap-conductive area of the trunk (sapwood), performs fast and successive readings on each thermocouple sensor at different sapwood depths and compares the temperatures at constant distances upstream $\left(X_{d}=10 \mathrm{~mm}\right)$ and downstream $\left(X_{u}=-5 \mathrm{~mm}\right)$ from the heat source until the temperatures becomes equal at each depth. The data-logger then records the corresponding elapsed time from the release of the heat pulse $t_{z}$ in $s$. The procedure ends when all probes $t_{z}$ values are found. The $t_{z}$ data is then analysed using the analysis software and the standard routine defined and implemented in the HPV2004 software designed for calculation of sap flows from $t_{z}$ cross-over time readings (Green, 2004). Conversions from time to heat-pulse velocity are done and sap flows are estimated considering also the properties of the woody matrix and the conducting 
sapwood cross-sectional area. Recorded sap flows are also corrected for probe-induced wounding effects in the stem that cause disruption of xylem tissue near the probes. The adopted $2.0 \mathrm{~mm}$ wound-width correction factor was based on calibration experiments conducted with similar probes in olive trees by Fernández et al. $(2001,2006)$. With this woundwidth factor they obtained the most accurate sap flow values for olive trees from measured heat-pulse values.

\subsection{Soil water measurements and water balance approach}

To evaluate soil water potential and moisture status in the $0.66 \mathrm{~m}$ wet bulb diameters developed by each of the twelve $3.61 \mathrm{~h}^{-1}$ emitters spaced $1 \mathrm{~m}$ apart in the $12 \mathrm{~m}$ by $12 \mathrm{~m}$ tree layout and along the emitter line of the irrigation treatment, sets of soil water potential watermark sensors (Shock et al.,1998; Irrometer Co. Inc., Riverside, California) and Profile Probe-PR1 (Delta T Devices Ltd., Cambridge, UK) soil water content sensors were installed near the trunk of two representative trees and at various depths into the soil. The water potential and profile probe sensors were placed at the wet bulbs located 1 and $3 \mathrm{~m}$ from the tree trunk along the tree drip line at $0.25,0.45,0.65 \mathrm{~m}$ depths and $0.10,0.20,0.30$ and $0.40 \mathrm{~m}$ depths, respectively. Soil samples taken in the olive orchard indicated a clay soil at $0.45 \mathrm{~m}$ and silt loam below, underneath which a restrictive layer of very compact limestone and schist prevented further placement of sensors below $0.65 \mathrm{~m}$ depth. Table 1 presents the soil characteristics. Table 2 shows the relevant soil parameters associated with the soil water retention and hydraulic conductivity properties presented in Fig. 2 and associated to the Mualem-van Genuchten model (Fares \& Alva, 2000, van Genuchten, 1980). A suction crust infiltrometer similar in design to that described by Booltink et al. (1991) was used to evaluate the saturated hydraulic conductivity of the soil. Watermark granular matrix block sensors are affordable, easy

Table 1 - Physical and chemical soil characteristics of soil profile in the mature olive stand

\begin{tabular}{|c|c|c|c|}
\hline Depth, cm & $0-18$ & $18-45$ & $45-65$ \\
\hline Texture & Clay & Clay & $\begin{array}{l}\text { Silt } \\
\text { loam }\end{array}$ \\
\hline Sand, \% & 35.8 & 27.3 & 44.0 \\
\hline Silt, \% & 15.8 & 18.9 & 32.6 \\
\hline Clay, \% & 48.4 & 53.8 & 23.4 \\
\hline Expansibility, \% & 8.38 & 4.55 & 2.50 \\
\hline Bulk density, $\mathrm{Mg} \mathrm{m}^{-3}$ & 1.52 & 1.64 & - \\
\hline $\begin{array}{l}\text { Total porosity, } \\
\mathrm{cm}^{3} \mathrm{~cm}^{-3}\end{array}$ & 0.43 & 0.40 & - \\
\hline $\mathrm{pH}\left(\mathrm{H}_{2} \mathrm{O}\right)$ & 8.19 & 8.34 & 8.82 \\
\hline $\mathrm{CaCO}_{3}, \%$ & 7.70 & 40.5 & 39.6 \\
\hline $\begin{array}{l}\text { Electric Conductivity } \\
\text { (EC), } \mathrm{dS} \mathrm{m}^{-1}\end{array}$ & 0.36 & 0.28 & 0.19 \\
\hline $\begin{array}{l}\text { Sodium Absorption } \\
\text { Ratio (SAR), meq } 1^{-1} 0.5\end{array}$ & 0.19 & 0.16 & 0.29 \\
\hline
\end{tabular}

Table 2 - Adjustment parameters of the Mualem-van Genuchten model for soil water retention and hydraulic conductivity curves obtained from soil samples collected at the Herdade dos Lameirões

\begin{tabular}{lr}
\hline Parameter & Value \\
\hline Residual water content $\theta_{\mathrm{r}}, \mathrm{cm}^{3} \mathrm{~cm}^{-3}$ & 0.2202 \\
Saturation water content $\theta_{\mathrm{s}}, \mathrm{cm}^{3} \mathrm{~cm}^{-3}$ & 0.4000 \\
Saturated hydraulic conductivity $\mathrm{K}_{\mathrm{s}}, \mathrm{m} \mathrm{d}^{-1}$ & 0.1761 \\
Fitting parameter $\alpha$ & 0.1407 \\
Fitting parameter $n$ & 1.2316 \\
Fitting parameter $\lambda$ & -5.4888 \\
\hline
\end{tabular}

to install, require virtually no maintenance and are suitable for continuous and automated data recording via a datalogger. They consist of two concentric electrodes buried in a granular matrix material where, depending on the pressure balance between the block and the adjacent soil, soil moisture is constantly absorbed or released from it. As the soil dries out due to the flow of water from the block into the surrounding soil and the sensor moisture is reduced, the soil water pressure around the sensor decreases. This loss of water is sensed as an increase in the electrical resistance between the electrodes. The watermark sensor reading range of 0 to $-0.20 \mathrm{MPa}$ allows reliable sensing of soil water pressure potential only in the narrow limit of high soil wetness between 0.42 to $0.34 \mathrm{~cm}^{3} \mathrm{~cm}^{-3}$ in the top layer and 0.39 to $0.31 \mathrm{~cm}^{3} \mathrm{~cm}^{-3}$ in the root zone as Table 3 illustrates, very close to the soil field capacity values of $0.36 \mathrm{~cm}^{3} \mathrm{~cm}^{-3}$ in the top layer and $0.34 \mathrm{~cm}^{3} \mathrm{~cm}^{-3}$ in the root zone. To evaluate the soil temperature and automatically correct for the watermark block resistance readings, for each set of watermark sensors, a thermocouple was installed at $0.25 \mathrm{~m}$ depth.

Soil water balance and water storage in the root zone were obtained using the following equation defined for a given time $\Delta t$ as

$\Delta S=R+I-D-E T_{C}$,

where $\Delta S$ is the variation in water storage in the root zone in $\mathrm{mm}$; $R$ is the measured rainfall in $\mathrm{mm}$; $I$ is the irrigation amount in $\mathrm{mm} ; \mathrm{D}$ is the drainage in $\mathrm{mm}$ and $\mathrm{ET}_{\mathrm{c}}$ is the crop evapotranspiration in $\mathrm{mm}$. A negligible water runoff was recorded. The average hourly watermark soil water potentials $\psi$ in bar at root depths of 0.25 and $0.45 \mathrm{~m}$ and below root depth $(0.65 \mathrm{~m})$, converted to water pressure head $h$, were used in the van Genuchten analytical equation, Eq. (2) to estimate soil water content, $\theta$ in $\mathrm{cm}^{3} \mathrm{~cm}^{-3}$ (van Genuchten, 1980; Fares \& Alva, 2000):

$\theta=\theta_{r}+\left(\theta_{s}-\theta_{r}\right)\left[1+(\alpha h)^{n}\right]^{-(1-1 / n)}$,

where $\theta_{r}$ is the residual water content in $\mathrm{cm}^{3} \mathrm{~cm}^{-3} ; \theta_{s}$ is the saturation water content in $\mathrm{cm}^{3} \mathrm{~cm}^{-3} ; \alpha$ and $n$ are fitting parameters and $h$ is the water pressure head in $\mathrm{cm}$. Subsequently, the variation in water storage $\Delta S$ between 0 and $0.5 \mathrm{~m}$ depth and within a time interval $\Delta t$ of $1 \mathrm{~h}$ was 

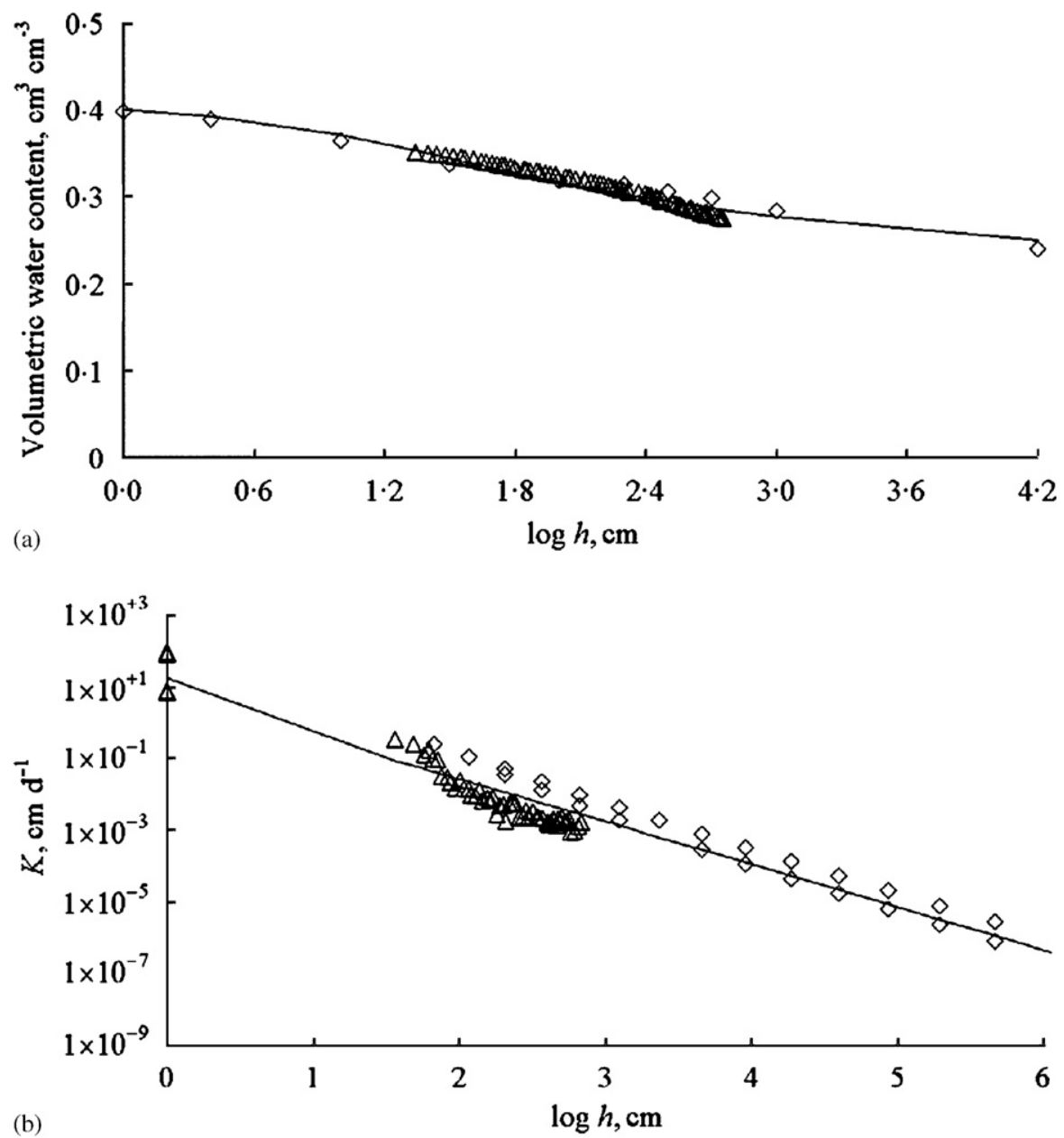

Fig. 2 - Curves obtained for soil profile samples collected at the experimental site of Herdade dos Lameirões, Moura, Portugal, using laboratory methods and adjusting with the Mualem-van Genuchten (M-vG) model parameters of Table 2: (a) soil water retention curve; $\diamond$, porous plate assembly (pressure chamber); $\triangle$, evaporation; —, M-vG; and (b) hydraulic conductivity $\mathrm{K}(\theta)$ $\left(\mathrm{cm} \mathrm{d}^{-1}\right.$ ) curves obtained for soil profile samples: $\diamond$, hot air; $\triangle$, evaporation ;,- M-vG.

Table 3 - Soil water retention values evaluated from clay soil samples collected at the Herdade dos Lameirões

\begin{tabular}{lcc}
\hline & \multicolumn{2}{c}{ Soil water content $\theta, \mathrm{cm}^{3} \mathrm{~cm}^{-3}$} \\
\cline { 2 - 3 } $\begin{array}{l}\text { Soil water } \\
\text { potential } \psi, \mathrm{MPa}\end{array}$ & \multicolumn{2}{c}{ Depth, $\mathrm{m}$} \\
\cline { 2 - 3 } & $\begin{array}{c}0-0.18 \\
\text { (top layer) }\end{array}$ & $\begin{array}{c}0.18-0.45 \\
\text { (root zone) }\end{array}$ \\
\hline-0.025 & 0.4229 & 0.3889 \\
-0.01 & 0.3878 & 0.3648 \\
-0.03 & 0.3596 & 0.3370 \\
-0.06 & 0.3497 & 0.3309 \\
-0.10 & 0.3430 & 0.3180 \\
-0.20 & 0.3357 & 0.3139 \\
-0.30 & 0.3285 & 0.3058 \\
-0.50 & 0.3207 & 0.2986 \\
-0.1 & 0.3086 & 0.2837 \\
-1.5 & 0.2675 & 0.2394 \\
\hline
\end{tabular}

obtained using Eq. (3).

$\Delta S=\int_{z_{1}}^{z_{2}} \theta\left(z, t_{1}\right) d z-\int_{z_{1}}^{z_{2}} \theta\left(z, t_{2}\right) d z$

where $z_{1}$ is the initial depth interval in $\mathrm{mm} ; \mathrm{z}_{2}$ is the final depth interval in $\mathrm{mm}$; $\mathrm{t}_{1}$ is the initial time interval in min and $t_{2}$ is the final time interval in min. Drainage below the root zone required for Eq. (1) was estimated using Eq. (4), where $\mathrm{K}(\mathrm{h})$ is the hydraulic conductivity in $\mathrm{cm} \mathrm{d}^{-1}$ at the corresponding water pressure head $h$ of the soil layer:

$D=K(h) \frac{\Delta(h+z)}{\Delta z} \Delta t$

The unsaturated hydraulic conductivity $K(h)$ of Eq. (4) was estimated using Eq. (5) of Mualem-van Genuchten

$K(h)=K_{s} \frac{\left(\left(1+(\alpha h)^{n}\right)^{1-1 / n}-(\alpha h)^{n-1}\right)^{2}}{\left(1+(\alpha h)^{n}\right)^{(1-1 / n)(\lambda+2)}}$, 
where $K_{\mathrm{s}}$ is the saturated hydraulic conductivity in $\mathrm{cm} \mathrm{d}^{-1}, h$ is the water pressure head in $\mathrm{cm}$ at which $K(h)$ is being calculated and $\lambda$ is a fitting parameter.

\section{Results}

3.1. Transpiration rates and daily environmental climatic changes

Fig. 3 shows a typical 5-day period pattern of sap flow variation for the two monitored olive trees under treatments $A$ and $C$ in response to daily local atmospheric evaporative demand. In general, monitored half-hour sap flow rates were responsive to daily climatic and even brief environmental changes such as the passing of clouds, as seen from the fluctuations in short-term sap flow from May 10 to May 12. With the two treatments in the period between May 8 and May 13 under the same irrigation water regime, the shapesimilarity of both sap flow curves shows the same shaperesponse to local atmospheric daily evaporative demands. The recorded differences in daily sap flow rate amplitude caused by plant absorption of solar radiation are explained by the natural tree differences in canopy cover, plant height, and conductance of water vapour sites. Fig. 4 presents the prevailing daily meteorological variables influencing the daily evaporative demand causing the behaviour of sap flow rates variation and fluctuation presented in Fig. 3. The daily

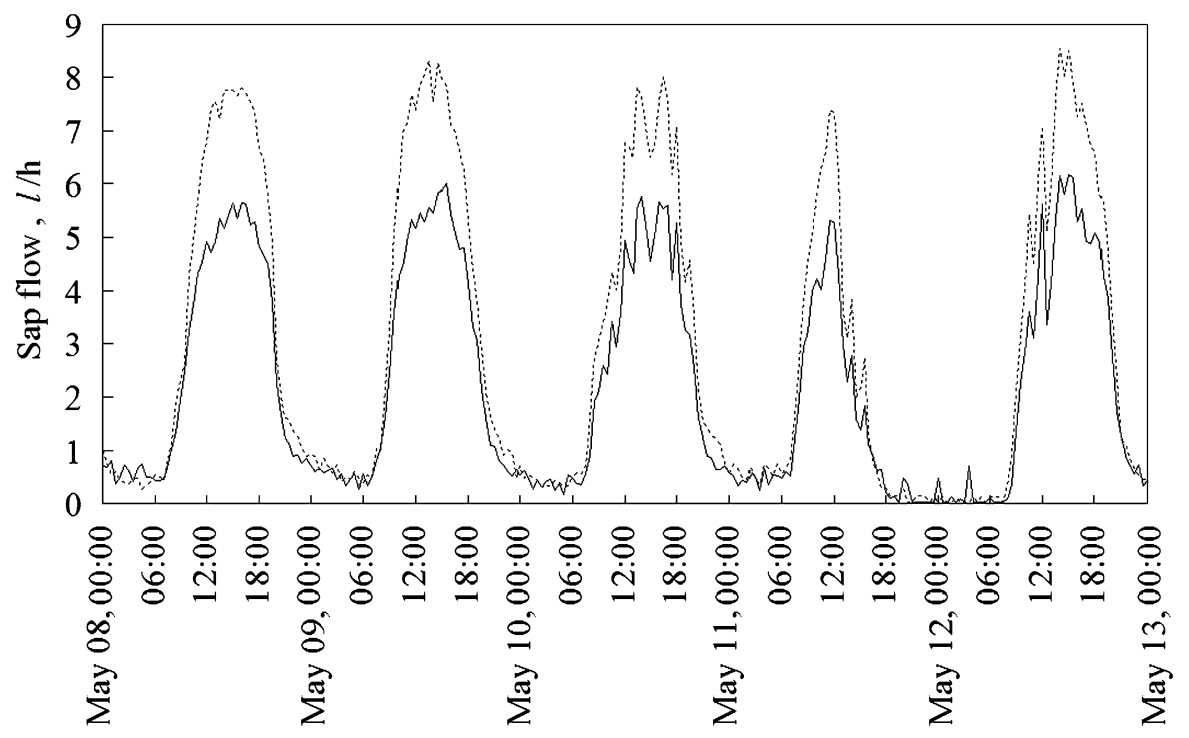

Fig. 3 - Five-day sample results of sap flow measurements in all monitored trees: - - - - -, sap flow in the mature olive tree with treatment $\mathrm{A} ; \ldots$, sap flow in the mature olive tree with treatment $\mathrm{C}$.

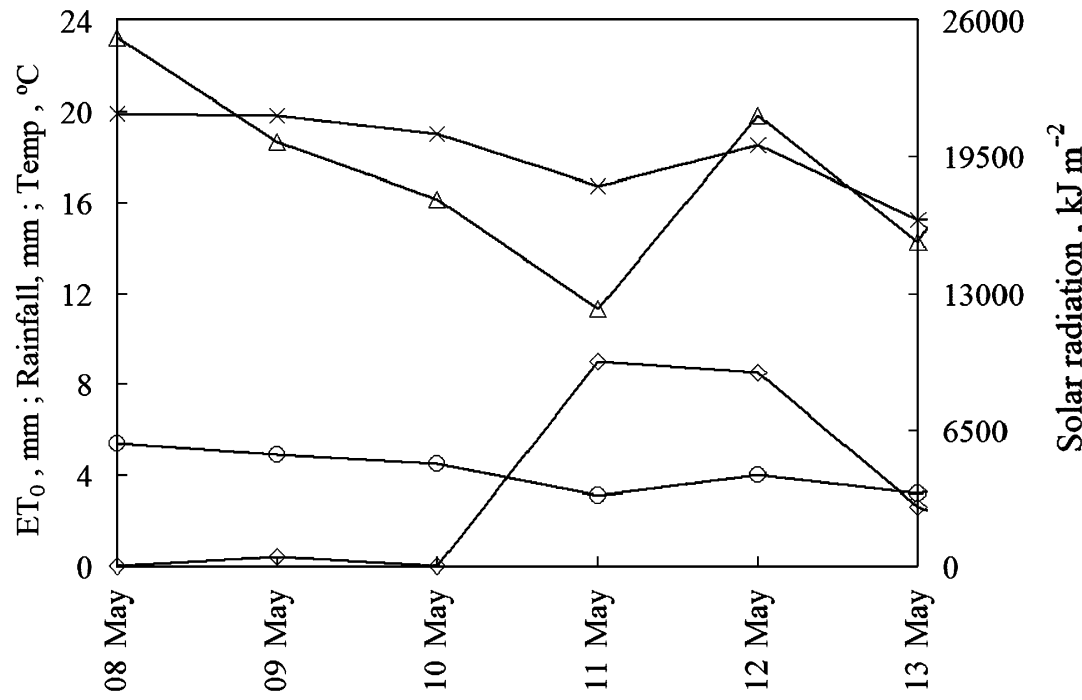

Fig. 4 - Daily meteorological variables recorded in an automatic weather station located near the olive tree stand and daily potential evapotranspiration $\left(\mathrm{ET}_{0}\right): \multimap, \mathrm{ET}_{0} ; \multimap$, rainfall; $\rightarrow$, average daily temperature; $\AA$, solar radiation. 
changes in the weather data of Fig. 4, responsible also for the changes in the presented FAO-Penman-Monteith (Allen et al., 1998) potential evapotranspiration $\mathrm{ET}_{0}$, indicate that the pattern of daily sap flow variation rates of Fig. 3 are in agreement with the daily variations in meteorological parameters. For the 5-day period, the lowest sap flow rate was recorded on May 11, coincident with a significant change in the prevailing weather, occurrence of a considerable rainfall of $9 \mathrm{~mm}$ and a cloudy day. Such facts decreased the daily average air temperature, solar radiation and, subsequently, the atmospheric demand for water as the sudden drops in sap flow rates well indicate. This close relationship between atmospheric changes and the concurrent changes in sap flow rates were observed throughout the 4 month period of sap flow monitoring.

Whereas trees under treatment A were constantly irrigated throughout the irrigation period to daily supply for their evapotranspiration needs, trees under treatment $C$, similarly watered since the onset of irrigation in March, ceased being irrigated between May 15 and July 4. This gradually affected the ability of trees under treatment $C$ to adequately respond to the evaporative demands of the day, presenting smaller amplitudes of sap flow variation after mid-May as Fig. 5 shows. Irrigation was resumed on June 4. Fig. 6 shows for the two treatments the typical long-term impact of meteorological changes on daily reference evapotranspiration $\mathrm{ET}_{0}$ and the recorded olive tree sap flow rates. The nonwatering of treatment $C$ between May 15 and June 4 increased the discrepancy between sap flow and evapotranspiration rates; serious after May 23. Allen et al. (1998) indicate that for a given vegetation surface, potential evapotranspiration depends only on the net radiant energy absorbed by the surface, the air temperature and the corresponding water vapour pressure deficit. Water potential differences between the tree xylem and

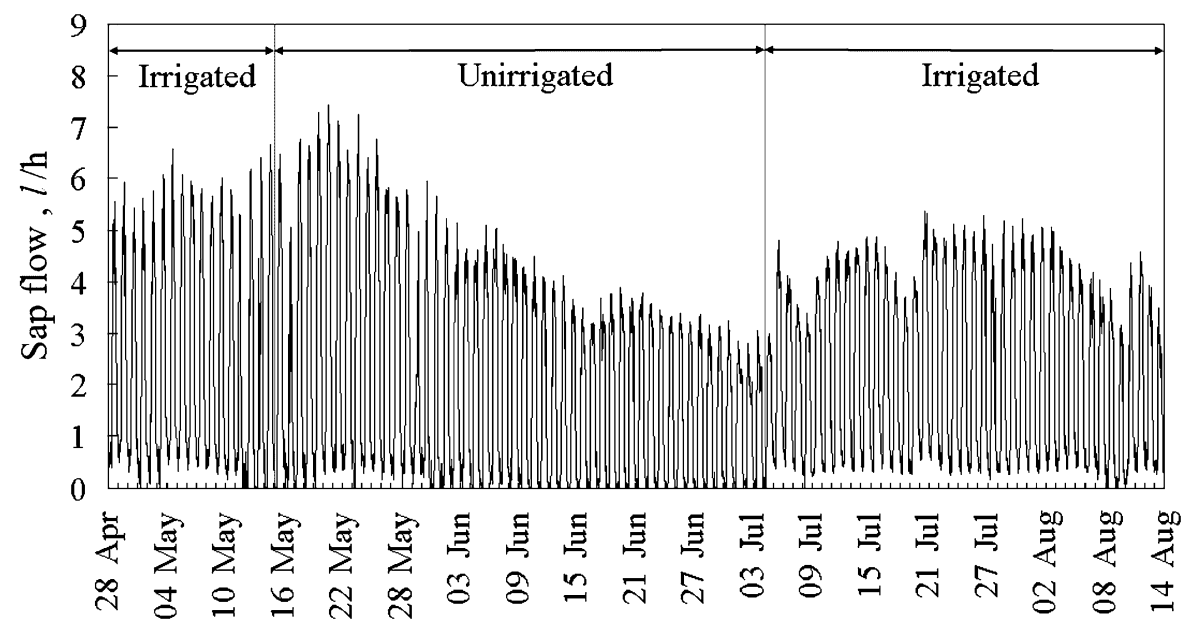

Fig. 5 - Sap flow rates measured in the mature olive tree under treatment $\mathrm{C}$.

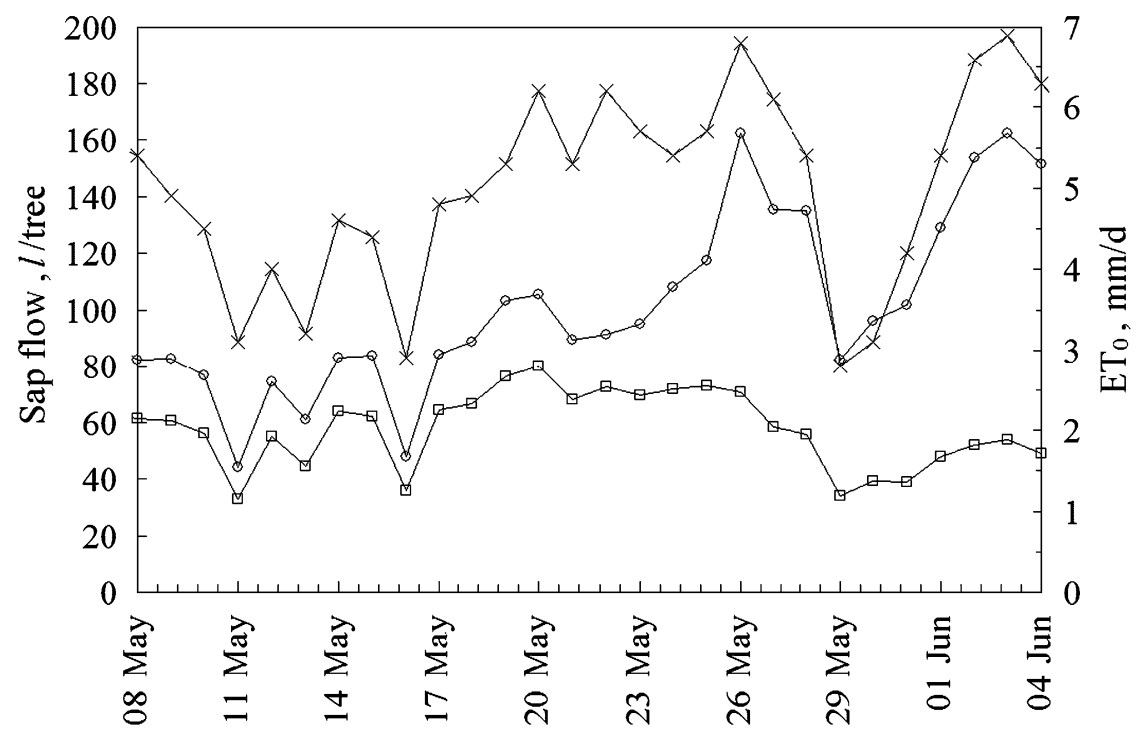

Fig. 6 - Daily sap flow measured on sampled trees in treatments $A$ and $C$ and FAO-Penman-Monteith potential evapotranspiration $\left(E T_{0}\right)$ computed by the local automatic weather station: $\longrightarrow \leftarrow, E T_{0} ; \multimap$, sap flow measured in treatment $A ; \square$, sap flow measured in treatment $C$. 
the surrounding environment monitored as sap flow rates are, as a consequence, closely related to the prevailing estimates of evapotranspiration. A universally accepted quantifier of the evaporative demands of the atmosphere influencing primarily the water vapour flux density of vegetated surfaces, transpiration is quantified here as sap flow rates (Green \& Clothier, 2003; Valverde, 2004). Accordingly, Fig. 6 shows daily sap flow rates of the well-watered treatment A closely following daily evapotranspiration trend of variation throughout the irrigation period and whilst with the deficit irrigated treatment $C$ sap flows diverged from that trend during the period of nonirrigation between May 15 and June 4 .

\subsection{Transpiration rates and soil water status}

According to the regulated deficit irrigation prescribed for treatment C, after flowering in May, the trees were not watered between May 15 and July 4. Irrigation was resumed thereafter. Fig. 5 presents the on-and-off irrigation periods and the corresponding average daily sap flow rates. After the shut down of irrigation on May 15, sap flow rate, taken here as transpiration rate, gradually decreased from its maximum of $71 \mathrm{~h}^{-1}$, when the trees were fully irrigated and soil water content was near field capacity, to values of less than $31 \mathrm{~h}^{-1}$ by July 3 as soil water content gradually reduced, thus acting as the transpiration limiting factor. Transpiration rates recovered after irrigation and were re-introduced on July 4.

Transpiration rates of treatment $C$ shown in Fig. 5, although low in the period of non-irrigation never dropped to zero. Trees, in the absence of irrigation and making use of the extensive root system developed under dry-farming were able to extract soil water in the large soil volume of the $12 \mathrm{~m}$ by $12 \mathrm{~m}$ tree spacing. This creates a recognisable problem in the monitoring of soil water status in orchards recently converted to irrigation as it is difficult to obtain reliable and representative soil water information of the whole tree root zone volume with the few sensors placed at the drip irrigation emitter wet bulb area.

Scarce water resources, caused by a dry hydrological year with only $194 \mathrm{~mm}$ rainfall which was well below the $580 \mathrm{~mm}$ expected average for the region, precluded the trees being irrigated during the month of August. The last irrigation of July 27 and the two rainfall events of August were not enough to provide for the prescribed water allotment for the month. This is noticeable in Fig. 5 where it that shows a partial recovery of transpiration rates after the irrigation events of July but to levels lower than those observed prior to May 15 and with a significant reduction during the month of August. Table 4 shows the scheduling and amounts of irrigation supplied to treatment $A$ and $C$ trees in the period between the months of March and August. Rainfall amounts were low and did not account for significant changes in soil water content or in trees water uptake, except for a slight increase in soil water observed after the rainfall of August 9.

\subsection{Olive orchard water balance and use}

According to Xiloyannis et al. (1999), the ability of olive trees to cope with drought and soil water scarcity allows them to establish high potential gradients between the leaves and roots and extract water held in the soil with tension up to $-2.5 \mathrm{MPa}$, well below the traditionally accepted crop wilting tension threshold of $-1.5 \mathrm{MPa}$. The $-2.5 \mathrm{MPa}$ is also well below the watermarks $-0.20 \mathrm{MPa}$ lower limit of reading and, as a result, watermark sensors may fail to account for all the water in the soil available for plant use. This is noticeable in Fig. 7 which shows the evolution of watermark soil water potential readings for treatments A and C between April 28 and August 14. On both treatments, watermark sensors were able to capture the variations of soil water potential in the periods of irrigation when the soil water content was high, but failed to provide meaningfully values for the low soil

Table 4 - Rainfall and irrigation supplied to trees in the mature olive stand under full irrigation (treatment A) and regulated deficit irrigation (treatment C) during 2005

\begin{tabular}{|c|c|c|c|c|c|c|}
\hline \multirow[t]{2}{*}{ Start } & \multirow[t]{2}{*}{ End } & \multirow{2}{*}{$\begin{array}{l}\text { Rainfall, } \\
\text { mm }\end{array}$} & \multicolumn{2}{|c|}{ Mature olive trees treatment A } & \multicolumn{2}{|c|}{ Mature olive trees treatment C } \\
\hline & & & $\begin{array}{l}\text { Irrigation, } \\
\text { l/tree }\end{array}$ & $\begin{array}{l}\text { Daily average } \\
\text { irrigation, l/tree }\end{array}$ & $\begin{array}{l}\text { Irrigation, } \\
\text { l/tree }\end{array}$ & $\begin{array}{l}\text { Daily average } \\
\text { irrigation, l/tree }\end{array}$ \\
\hline 18-Mar & 31-Mar & 11.6 & 432.0 & 30.9 & 432.0 & 30.9 \\
\hline 01-Apr & 15-Apr & 19.3 & 864.0 & 57.6 & 864.0 & 57.6 \\
\hline 16-Apr & 28-Apr & 0.9 & 496.8 & 38.2 & 496.8 & 38.2 \\
\hline 29-Apr & 12-May & 17.9 & 864.0 & 61.7 & 864.0 & 61.7 \\
\hline 13-May & 26-May & 10.2 & 907.2 & 64.8 & 129.6 & 9.3 \\
\hline 27-May & 09-Jun & 3.1 & 1166.4 & 83.3 & 0.0 & 0.0 \\
\hline 10-Jun & 24-Jun & 4.4 & 1684.8 & 112.3 & 0.0 & 0.0 \\
\hline 25-Jun & 06-Jul & 0.0 & 1728.0 & 144.0 & 432.0 & 36.0 \\
\hline 07-Jul & 19-Jul & 0.0 & 1036.8 & 79.8 & 1036.8 & 79.8 \\
\hline 20-Jul & 03-Aug & 0.6 & 1036.8 & 69.1 & 1036.8 & 69.1 \\
\hline 04-Aug & 17-Aug & 1.1 & 0.0 & 0.0 & 0.0 & 0.0 \\
\hline 18-Aug & 09-Sep & 0.0 & 0.0 & 0.0 & 0.0 & 0.0 \\
\hline
\end{tabular}



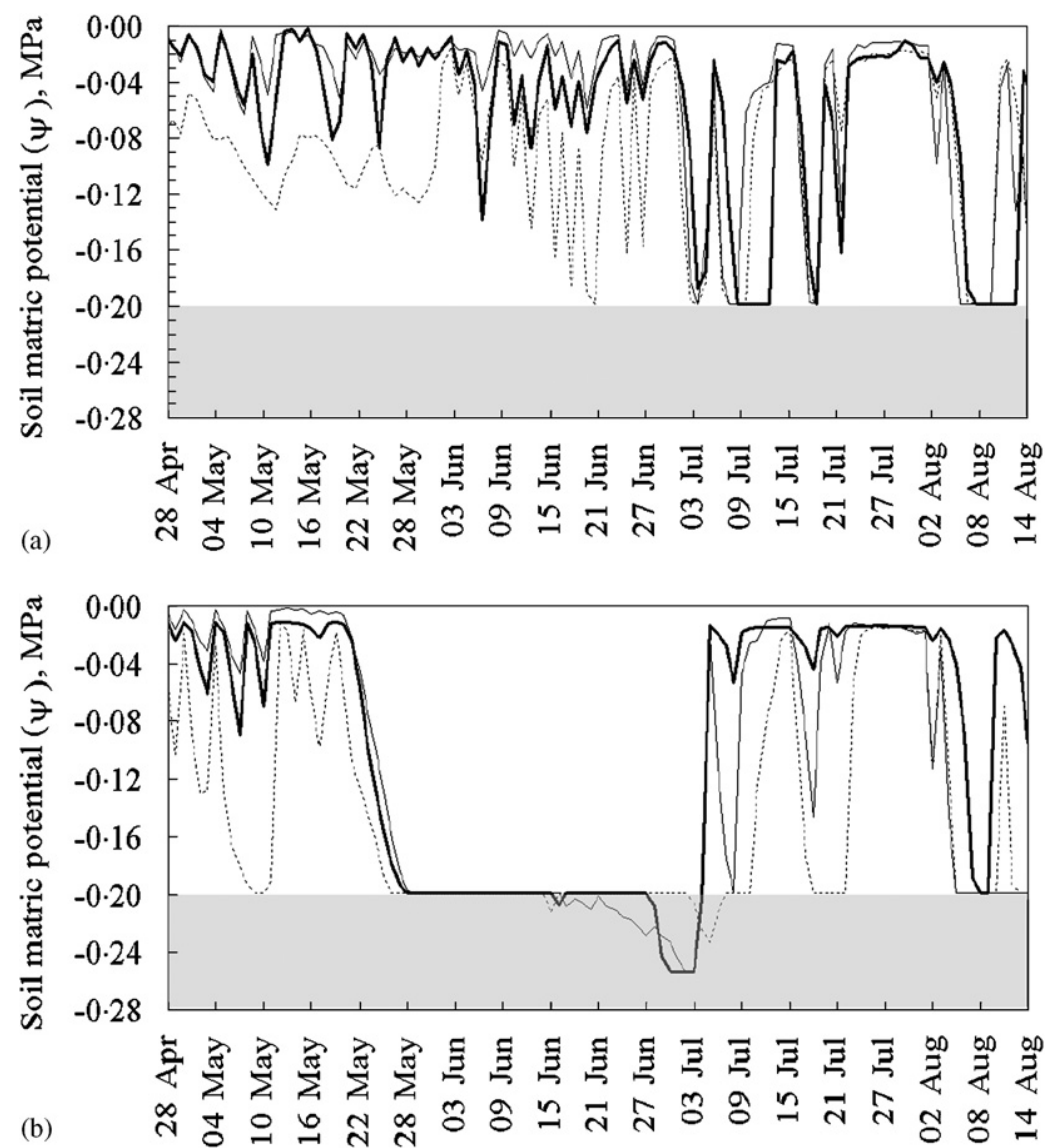

Fig. 7 - (a) Soil water potentials of mature olive stand under treatment A evaluated with watermark sensors placed in the drip emitter's wet bulb at the depths of: —_, $0.25 \mathrm{~m} ;-, 0.45 \mathrm{~m} ;----, 0.65 \mathrm{~m}$; $\square$, dark area shows the soil matric potential value range where the watermark sensors are unable to provide for reliable readings; (b) soil water potentials of mature olive stand under treatment $C$ evaluated with watermark sensors placed in the drip emitter's wet bulb at the depths of:

$0.25 \mathrm{~m}$; $0.45 \mathrm{~m} ;-\cdots, 0.65 \mathrm{~m} ; \mathrm{n}$, dark area shows the soil matric potential value range where the watermark sensors are unable to provide for reliable readings.

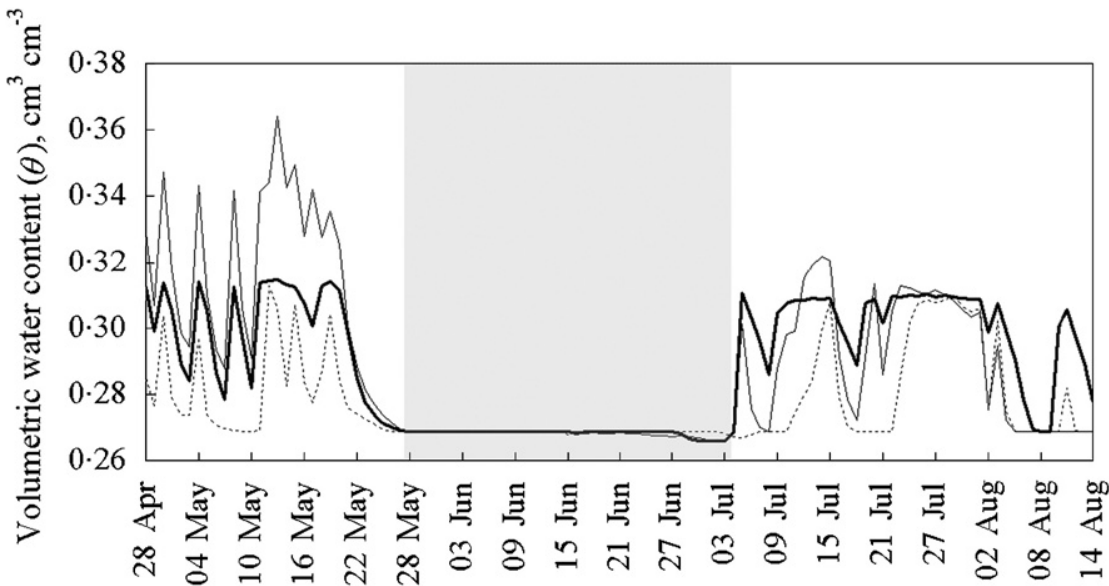

Fig. 8 - Soil volumetric water content in the mature olive stand under treatment C estimated using Eq. (2) with the watermark sensors readings placed in the drip emitter's wet bulb at the depths of: $0.25 \mathrm{~m}$; $0.45 \mathrm{~m} ;--., 0.65 \mathrm{~m} ; \mathbf{\square}$, dark area shows the period in which the watermark sensors reached or fell outside the instrument's measuring minimum limit after the shut down of irrigation in treatment $\mathrm{C}$, thus the real volumetric water content is likely lower than the computed values using this method. 
water potential values in the May 28 to July 4 period of nonirrigation when treatment $C$ soil water potentials dropped below $-0.2 \mathrm{Mpa}$. The shaded area in the figure indicates the range where watermark sensors were unable to provide for reliable readings for soil water potential.

Fig. 8 shows corresponding values of soil water content estimated from the watermark water potential readings of treatment C. Only above the soil water threshold value of $0.27 \mathrm{~cm}^{3} \mathrm{~cm}^{-3}$ did the watermarks sense and adequately described depth and time variations of soil volumetric water content. As a result, the watermarks failed to account for much of the water available in the soil during the nonirrigation period. This can be confirmed by comparing watermark values with profile probe soil water content values in Fig. 9 where there is evidence of water availability in the soil well below the watermark lower limit water content of $0.27 \mathrm{~cm}^{3} \mathrm{~cm}^{-3}$ for treatment C. As Fig. 9 shows, a considerable amount of water is held in the soil below the $10 \mathrm{~cm}$ depth long after irrigation is reduced and it is made available for daily partial support of the tree transpiration rate. This water storage, capable of supplying the trees with water to partially support their daily transpiration rates, is unaccounted for by the watermark sensors. Fig. 10 shows the corresponding treatment $C$ water storage in the root zone for the period. Water storage reached a maximum value of $142 \mathrm{~mm}$ in May 12 and gradually dropped to around a minimum value of $90 \mathrm{~mm}$; still a significant value to consider in the long period of nonirrigation.

Fig. 10 also contrasts soil water storage of treatments $C$ and A, the latter being obtained from volumetric water content values presented in Fig. 11 and evaluated from profile probe sensor readings. As treatment A prescribes, trees were kept under high water content throughout the irrigation period and, consequently, the soil presents higher water storage

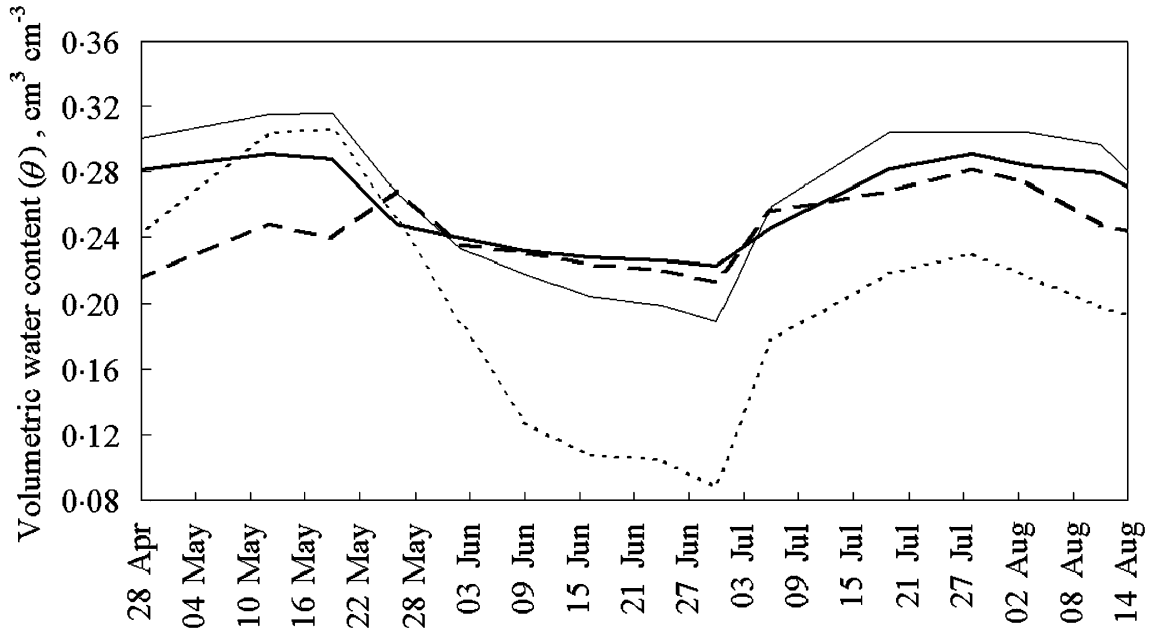

Fig. 9 - Soil volumetric water content in the mature olive stand under treatment C estimated using the Delta T PR1 Profile probe readings with sensors placed in the drip emitter's wet bulb at the depths of: - - - -, 0.10m; $\longrightarrow, 0.20 \mathrm{~m} ;-, 0.30 \mathrm{~m}$; ,$- 0.40 \mathrm{~m}$.

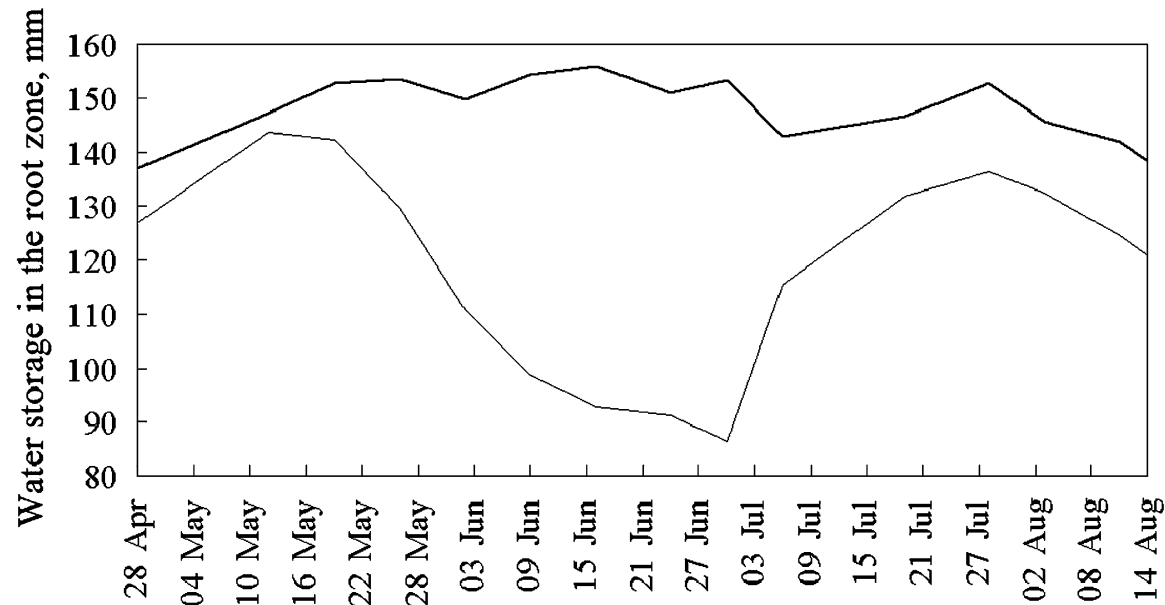

Fig. 10 - Water storage in the root zone estimated for the mature olive stand under treatments A and C with a Delta T PR1 probe: —_, water storage in treatment $\mathrm{A} ; \ldots$, water storage in treatment $\mathrm{C}$. 


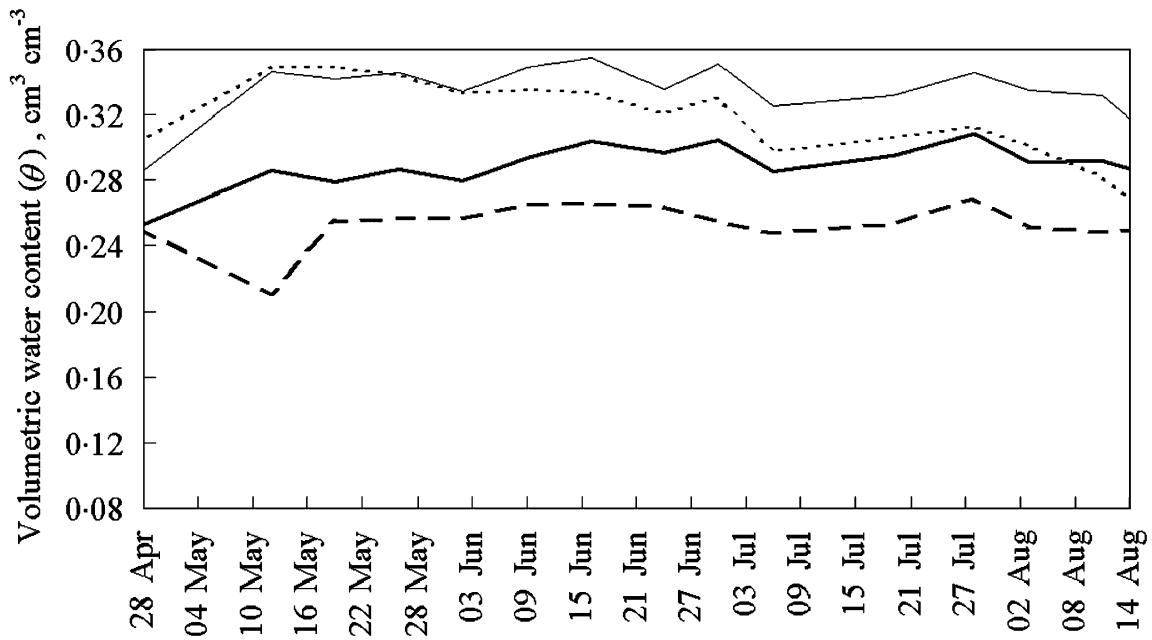

Fig. 11 - Soil volumetric water content in the mature olive stand under treatment A estimated using the Delta T PR1 Profile probe readings with sensors placed in the drip emitter's wet bulb at the depths of:,$---- 0.10 \mathrm{~m} ; \longrightarrow, 0.20 \mathrm{~m} ;-, 0.30 \mathrm{~m}$; ,$- 0.40 \mathrm{~m}$.

Table 5 - Crop evapotranspiration $\mathrm{ET}_{\mathrm{c}}$ rates per tree estimated for the mature olive trees under full irrigation (treatment $\mathrm{A}$ ) and under regulated deficit irrigation (treatment C) from soil water balance using soil sensors (watermark and Delta T PR1 probe) in the wet bulb developed by the drip irrigation emitters and corresponding tree transpiration estimated from sap flow rates during the period considered for each treatment

\begin{tabular}{|c|c|c|c|c|c|c|c|}
\hline \multicolumn{2}{|c|}{ Date interval } & \multicolumn{3}{|c|}{ Mature olive trees treatment A } & \multicolumn{3}{|c|}{ Mature olive tree treatment $\mathrm{C}$} \\
\hline Start & End & $\begin{array}{c}{E T_{c}}_{c} \text { from soil } \\
\text { water } \\
\text { balance With } \\
\text { watermark } \\
\text { sensors, } 1 / d\end{array}$ & $\begin{array}{c}E T_{c} \text { from soil } \\
\text { water } \\
\text { balance with } \\
\text { profile probe, } \\
\text { l/d }\end{array}$ & $\begin{array}{l}\text { Transpiration } \\
\text { from sap flow } \\
\text { rates, } 1 / d\end{array}$ & $\begin{array}{c}\mathrm{ET}_{\mathrm{c}} \text { from soil } \\
\text { water } \\
\text { balance with } \\
\text { watermark } \\
\text { sensors, } \mathrm{l} / \mathrm{d}\end{array}$ & $\begin{array}{c}E T_{c} \text { from soil } \\
\text { water } \\
\text { balance With } \\
\text { profile probe, } \\
\text { l/d }\end{array}$ & $\begin{array}{l}\text { Transpiration } \\
\text { from sap flow } \\
\text { rates, } 1 / d\end{array}$ \\
\hline 18-Mar & 31-Mar & 25.0 & NA & NA & 23.7 & NA & NA \\
\hline 01-Apr & 15-Apr & 62.4 & 54.6 & 55.0 & 61.8 & 58.1 & 41.0 \\
\hline 16-Apr & 28-Apr & 36.6 & 41.3 & 57.9 & 36.0 & 42.4 & 42.9 \\
\hline 29-Apr & 12-May & 58.6 & 59.7 & 79.4 & 60.6 & 57.9 & 58.1 \\
\hline 13-May & 26-May & 71.1 & 65.9 & 94.3 & 21.7 & 16.4 & $65.7\left({ }^{*}\right)$ \\
\hline 27-May & 09-Jun & 80.6 & 84.0 & 145.1 & 1.2 & 9.9 & $50.4(*)$ \\
\hline 10-Jun & 24-Jun & 76.6 & 114.4 & NA & 1.2 & 3.3 & $40.1\left(^{*}\right)$ \\
\hline 25-Jun & 06-Jul & 127.5 & 146.8 & NA & 32.7 & 27.7 & $36.9\left(^{*}\right)$ \\
\hline 07-Jul & 19-Jul & 79.2 & 85.1 & NA & 75.5 & 80.9 & 54.7 \\
\hline 20-Jul & 03-Aug & 69.2 & 69.6 & NA & 67.2 & 69.1 & 57.8 \\
\hline 04-Aug & 17-Aug & 7.2 & 3.5 & NA $\left({ }^{*}\right)$ & 0.4 & 4.8 & $44.7\left(^{*}\right)$ \\
\hline 18-Aug & 09-Sep & 2.0 & 3.5 & NA $\left(^{*}\right)$ & 0.0 & 9.4 & NA $\left({ }^{*}\right)$ \\
\hline
\end{tabular}

values than observed for treatment $\mathrm{C}$, never dropping below $140 \mathrm{~mm}$. The resulting evapotranspiration rates from profile probe shown in Table 5 for treatment A are consequently high, indicating that until the month of August, irrigation provided water for the daily evapotranspiration rate of trees. Also, the close agreement between evapotranspiration values obtained for treatment A with the watermark and profile probe sensors indicated that water balance method adequately evaluated the soil water content of treatment A, suggesting that both sensors can be used with confidence in management of olive trees subjected to full irrigation. As for treatment $\mathrm{C}$, transpiration rates from sap flow presented in
Table 5 although low in the period of non-irrigation between May 27 and June 9 stayed within 37 and $501 \mathrm{~d}^{-1}$ and never dropped to values close to zero as did evapotranspiration estimates from watermark and profile probe sensors. Such discrepancy suggests that in the absence of irrigation, and due to their extensive root system developed under dry farming, olive trees were able to extract soil water in the $12 \mathrm{~m}$ by $12 \mathrm{~m}$ tree spacing to maintain transpiration to levels as high as $50 l d^{-1}$ between May 27 and June 9 and $401 d^{-1}$ between June 10 and June 24 while soil water balance estimated the related tree evapotranspiration rates to as low as 1.2 and $9.91 \mathrm{~d}^{-1}$ in the drip irrigation wet bulbs. 
The observed differences between evapotranspiration and transpiration rates in the period of non-irrigation of treatment $C$ indicate that both sensors were unable to account for the real water uptake of olive trees during the period. They should be used with precaution in the control of regulated deficit irrigation (RDI) of orchards recently converted to irrigation, as with them it is difficult to obtain reliable and representative soil water information of the whole tree root zone volume. Rather than relying on soil moisture status, tree transpiration values presented in Table 5 indicate the compensation heat-pulse method as a more reliable approach to monitor plant water status and its physiological response to soil water availability and local atmospheric evaporative demands.

\section{Conclusions}

Traditionally a rain-fed crop, olive tree orchards have always played an important role in the rural economy of Portugal. Grown in areas where water is scarce even for human consumption, the large conversion and expansion of rainfed orchards to irrigation taking place in Southern Portugal makes the water use and irrigation optimisation of these orchards of crucial importance. The issue has been analysed in the study by field trials of full and deficit irrigated trees using the water balance approach and the compensation heat-pulse method for sap flow rate evaluation. With both treatments monitored half-hour sap flow rates were responsive to daily climatic changes. When trees were fully irrigated observed differences in daily sap flow rate amplitude due to plant absorption of solar radiation were explained by natural differences in canopy cover, plant height, and conductance of water vapour sites. However, when deficit irrigation is prescribed to fully irrigated trees and when they are stopped being irrigated, they gradually lost their ability to adequately respond to the evaporative demands of the day, presenting smaller amplitudes of sap flow variation. After the shut down in irrigation, transpiration rate gradually decreased from its maximum of $71 \mathrm{~h}^{-1}$, when trees were fully irrigated and soil water content was near field capacity, to values of less than $31 \mathrm{~h}^{-1}$, as soil water content gradually drops, thus acting as the transpiration limiting factor. Transpiration rates recover after irrigation is resumed, also indicating that soil water availability was limiting transpiration. Transpiration rates although low in the non-irrigation period remained between 37 and $50 \mathrm{ld}^{-1}$ and never dropped to zero as trees were able to extract water held in the soil in the absence of irrigation and long after its shut down. Differences between evapotranspiration and transpiration rates also indicate that in the period of non-irrigation, olive trees are able to extract soil water and maintain transpiration rates to levels as high as $50 \mathrm{ld}^{-1}$. For the same period, lower soil water balance evapotranspiration estimates of 1.2 to $10 \mathrm{ld}^{-1}$ carried out within the drip emitter wetting area with watermark and capacitance sensors indicate that both instruments underestimate tree water uptake and should not be used for control of dry-farmed olive trees subject to deficit irrigation. The particular ability of those trees to use water held in the soil under very low potential and the uncertainties associated with assessment of the real volume of soil effectively explored by the root system, make tree water uptake tree estimates from soil water balance in the drip irrigation unreliable under deficit irrigation. Nevertheless, both sensors were able to capture the variations of soil water while high and they could be used in management of full irrigated orchards. However, rather than relying on soil moisture status, tree transpiration rates indicate the compensation heat-pulse method is a more reliable approach to monitor water use and response of olive orchards recently converted to irrigation.

\section{Acknowledgements}

This work was made possible by partial funding from the Integrated Development of the Alqueva Área Program (PEDIZA II) and by the Agricultural and Rural Development Operational Program AGRO (Medida 8, Acção 8.1, projecto AGRO 728). We acknowledge Engo Luis Boteta of the Centro Operativo e de Tecnologia de Regadio (COTR) and Engo Isaías Pisarra of the Direcção Regional de Agricultura do Alentejo (DRAAL) for his precious help with the field experiment.

\section{R E F E R E N C E S}

Allen R; Pereira L S; Raes D; Smith M (1998). Crop evapotranspiration, Guidelines for computing crop water requirements. FAO Irrigation and Drainage Paper No. 56, Rome

Booltink H W G; Bouma J; Giménez D (1991). A suction crust infiltrometer for measuring conductivity of unsaturated soil near saturation. Soil Science Society of America Journal, 55, 566-568

Fares A; Alva A K (2000). Soil water components based on capacitance probes in a sandy soil. Soil Science Society of America Journal, 64, 311-318

Fernández J E; Moreno F (1999). Water Use by the Olive Tree, pp 101-162. Water Use in Crop Production, Haworth Press

Fernández J E; Palomo M J; Diaz-Espejo A; Girón I F; Moreno F (1998). Measuring sap flow in olive trees: potentialities and limitations of the compensation heat-pulse technique. Fourth International Workshop on Measuring Sap Flow in Intact Plants, pp 31-42. IUFRO Publications, Mendel University

Fernández J E; Palomo M J; Diaz-Espejo A; Clothier B E; Green S; Girón I F; Moreno F (2001). Heat-pulse measurements of sap flow in olives for automating irrigation: tests, root flow and diagnostics of water stress. Agricultural Water Management, 51, 99-123

Fernández J E; Durán P J; Palomo M J; Diaz-Espejo A; Chamorro V; Girón I F (2006). Calibration of sap flow estimated by the compensation heat pulse method in olive, plum and orange trees: relationships with xylem anatomy. Tree Physiology, 26, 719-728

Green S R; Clothier B E (1988). Water use of kiwifruit vines and apple trees by the heat-pulse technique. Journal of Experimental Botany, 39, 115-123

Green S R; Clothier B E; Jardine B (2003). Theory and practical application of heat-pulse to measure sap flow. Agronomy Journal, 95, 1371-1379

Green S (2004). Measurements of Sap Flow by the Heat-Pulse Method-An Instruction Manual for the HPV System. Tranzflo nz Ltd., Palmerston, New Zealand

Jones H G (2004). Irrigation scheduling: advantages and pitfalls of plant-based methods. Journal of Experimental Botany, WaterSaving Agriculture Special Issue, 55(407), 2427-2436 
Shock C; Barnum M; Seddigh M (1998). Calibration of 'Watermark' Sensors for Irrigation Management. International Irrigation Show. The Irrigation Association, San Diego, California

Smith D; Allen S (1996). Measurement of sap flow in plant stems. Journal of Experimental Botany, 47, 1833-1844

Valverde P (2004). Medição e Modelação da Transpiração e Evapotranspiração em Olivais Regados [Measurement and
Modelling of Transpiration and Evapotranspiration of Irrigated Olive Trees.] Final Paper, University of Évora, Portugal

van Genuchten M Th (1980). A closed-form equation for predicting the hydraulic conductivity of unsaturated soil. Soil Science Society of America Journal, 44, 892-898

Xiloyannis C; Dichio B; Nuzzo V; Celano G (1999). Defence strategies of olive against water stress. Acta Horticulturae, 474, 423-426 